\title{
Evaluasi Peranan Wanita Menuju Keluarga Sehat dan Sejahtera (P2WKSS) di Kabupaten Serang Tahun 2017
}

\author{
Inne Hardiyanti \\ Universitas Sultan Ageng Tirtayasa, Indonesia \\ Innehardiyanti15@gmail.com
}

\section{Titi Stiawati}

Universitas Sultan Ageng Tirtayasa, Indonesia titistiawati@yahoo.co.id

\section{Ika Arinia Indriyany}

Universitas Sultan Ageng Tirtayasa, Indonesia Ikaarinia@fisip-untirta.ac.id

\begin{abstract}
Abstrak
Penelitian ini di latar belakangi oleh permasalahan kemiskinan pada lingkup keluarga. Salah satu upaya pemerintah untuk penanggulangan kemiskinan pada lingkup keluarga ialah dengan membentuk Program Terpadu Peningkatan Peranan Wanita Menuju Keluarga Sehat Dan Sejahtera (P2WKSS). Pada penelitian ini, peneliti memfokuskan pada bagiamana Evaluasi Program Terpadu Peningkatan Peranan Wanita Menuju Keluarga Sehat Dan Sejahtera (P2WKSS) Pada Dinas Tenaga Kerja dan Transmigrasi Kabupaten Serang Tahun 2017 Di Kecamatan Mancak yang mana seyogyannya program tersebut menjadi solusi dari permasalahan kemiskinan pada dilingkup desa binaan. Teori yang digunakan ialah teori Evaluasi William N Dunn (2008) yaitu Efektivitas, Efisiensi, Kecukupan, Pemerataan, Responsivitas, Ketepatan. Metode yang digunakan dalam penelitian ini ialah kualitatif deskriptif. Teknik pengumpulan data dilakukan dengan wawancara, observasi dan dokumentasi. Teknik keabsahan data yang peneliti gunakan ialah triangulasi sumber. Pemilihan informan dilakukan dengan teknik purposive. Hasil penelitian ini menunjukan bahwa Program Pelatihan Menjahit yang dilaksanakan di Desa Sangiang dan Desa Bale Kencana belum optimal. Hal ini dikarenakan kegiatan pelatihan yang dilakasanakan hanya selama 25 hari, sehingga tidak maksimal. Selain itu, mesin jahit yang pakai pelatihan hanya mesin jahit biasa dan jumlahnya terbatas, sehingga kemampuan para peserta pun terbatas, dan menyebabkan keterampilan yang dimiliki belum cukup untuk membuka usaha sendiri maupun bekerja pada perusahaan.
\end{abstract}

Katakunci: Evaluasi, Program P2WKSS, Disnakertrans Kabupaten Serang 


\section{Abstract:}

This research is based on the background of the problems poverty in the family sphere. One of the government's efforts to poverty countermeasures in the family sphere is to by forming Program Terpadu Peningkatan Peranan Wanita Menuju Keluarga Sehat Dan Sejahtera (P2WKSS). In this researching, researchers focused on how to Evalution Terpadu Peningkatan Peranan Wanita Menuju Keluarga Sehat Dan Sejahtera Program (P2WKSS) Departement of Labor and Transmigrastion Serang Regency 2017 in Mancak ,which is program the solution to the problem of poverty in the surrounding villages.Theory used in research is are theory of Evalution by William $\mathrm{N}$ Dunn in Nugroho (2008), The Effectiveness, Efficiency, Adequacy, Equity, Responsiveness, Accuracy. The method used this study is descriptive qualitative. Data collection techniques are carried by interview, observation and documentation. The validity technique that the researcher uses is source triangulation. The selection of informants by purposive technique. The results of this study indicate that the Tailoring Training Program implemented in Sangiang Village and Bale Kencana Village was not optimal. This is because the training carried out only for 25 days, is not optimal. In addition, sewing machines that can be used are only ordinary and limited, so that the participants' abilities are limited, and the ability needed to work in a company.

Keywords: Evalution, P2WKSS Program, Departement of Labor and Transmigrastion Serang Regency.

\section{Pendahuluan}

Kemiskinan ditandai dengan ketidakmampuan atas memenuhi kebutuhan dasar (Pangan, Sandang dan Papan). Ketidakmampuan dalam memenuhi kebutuhan yang di akibatkan oleh rendahnya pendapatan, akan berdampak pada berkurangnya kemampuan untuk memenuhi standar kesehatan dan standar pendidikan. Dengan kata lain pendapatan yang rendah membuat masyarakat tidak banyak memiliki kesempatan untuk mensejahterakan keluarganya. Keluarga miskin adalah keluarga yang memiliki penghasilan di bawah Rp 387.160 (Tiga Ratus Delapan Tujuh ribu Seratus Enam puluh Rupaih) perbulan (Sumber: BPS tahun 2017).

Faktor-faktor yang menyebabkan kemiskinan diantaranya yaitu rendahnya taraf pendidikan, rendahnya derajat kesehatan, terbatasnya lapangan kerja, kondisi keterisolasian, peminggiran kaum perempuan, dan sebagainya. Salah satu upaya pemerintah untuk penanggulangan kemiskinan pada lingkup keluarga ialah dengan membentuk Program Terpadu Peningkatan Peranan Wanita Menuju Keluarga Sehat Dan Sejahtera atau yang disingkat menjadi P2WKSS. P2WKSS, adalah peningkatan peranan perempuan yang diselenggarakan melalui serangkaian program, dengan menggunakan pola pendekatan lintas sektor dan lintas pelaku di daerah, yang diarahkan untuk meningkatkan kesejahteraan keluarga guna mencapai tingkat hidup 
yang berkualitas (Peraturan Menteri Dalam Negeri Nomor 26 Tahun 2009 pasal 1 ayat 4).

Adapun terkait sejarah P2WKSS sendiri diawali dengan pelaksanaan Crash Program Keluarga Sehat pada tahun 1978. Selanjutnya pada tahun 1979 menjadi program terpadu P2WKSS. P2WKSS mempunyai tujuan untuk meningkatkan kedudukan dan partisipasi perempuan dalam pembangunan dimulai dari lingkungan keluarga. Keluarga merupakan unit terkecil dalam lingkungan masyarakat, oleh sebab itu perwujudan keberhasilan dalam penyelenggaraan pembangunan harus dimulai dari upaya untuk meningkatkan kesejahteraan keluarga. Dengan memulai pembangunan ditingkat keluarga, pemerintah akan lebih mudah untuk mengawasi dan melaksanakan pemberdayaan, dengan memulai dari tingkat keluarga diharapkan nanti akan naik tingkat ke lintas komunitas, regional dan nasional.

Pada Peraturan Menteri Nomor 26 Tahun 2009 Tentang Pedoman Pelaksanaan Peningkatan Peranan Wanita Menuju Keluarga Sehat Dan Sejahtera di Daerah, dijelaskan bahwa P2WKSS dilaksanakan melalui 3 program utama, yaitu: Program Dasar, Program Ianjutan Dan Program Pendukung. Dalam program dasar yang sebagaimana dimaksud ialah meliputi pengumpulan data dasar dari masing-masing sektor yang terkait dalam kegiatan P2WKSS, penyusunan Rencana Kerja Kelompok, kegiatan penyuluhan, percepatan penuntasan wajib belajar pendidikan dasar 9 (sembilan) tahun dan pemberantasan buta aksara dan pendidikan karakter dan pekerti bangsa. Program Lanjutan meliputi pelayanan dan pendampingan. Selanjutnya yang terakhir yaitu Program Pendukung meliputi pemantauan dan evaluasi kegiatan yang berkelanjutan dan tindak lanjut seluruh aktivitas kelompok kegiatan.

Program P2WKSS telah tersebar diberbagai Provinsi di Indonesia. Program P2WKSS sudah menjadi agenda setiap tahunnya. Program ini sudah berjalan pada tahun 2001 di Provinsi Banten. Adapun kriteria Desa/Kelurahan yang dipilih ialah Desa/Kelurahan yang masuk dalam Kategori daerah Rawan Pendidikan, Rawan Ekonomi dan Rawan Kesehatan. Pelaksanaan Program P2WKSS melibatkan banyak Dinas/Instansi.

Dinas terkait diantaranya: DKBPPPA (Dinas Keluarga Berencana Pemberdayaan Perempuan dan Perlindungan Anak) Kabupaten Serang yang bertindak sebagai Leading sector. Adapun instan lainnya diantaranya Dinkes (Dinas Kesehatan), Dinas Pekerja Umum dan Penataan Ruang, Dinas Kependudukan dan Catatan Sipil, Dinas Sosial, Dinas Tenaga Kerja dan Transmigrasi, Dinas Koperasi dan Perdagangan, Dinas Lingkungan Hidup, Dinas Perpus dan Arsip Daerah, Dinas Perhubungan, Dinas Pertanian, Dinas Ketahanan Pangan dan Perikanan, Kementrian Agama, TP PKK, GOW Kabupaten Serang, Dinas Pariwisata, Pemuda dan Olahraga, Dindik, Badan Penanggulangan Bencana Dearah, Dinas Perumahan Pemukiman dan Tata Bangunan, dan lain-lain. Dalam pelaksanaan program P2WKSS disusun keanggotaan dalam bentuk Kelompok Kerja (POKJA). Adapun dalam pelaksanaanya mengunakan alokasi dana dari APBD (Anggaran Pendapatan Belanja Daerah). 
Program P2WKSS telah tersebar diberbagai Provinsi di Indonesia, dan pada Provinsi Banten program ini telah berjalan pada tahun 2009. pada wilayah Kabupaten/Kota, Peneliti memilih Kabupaten Serang menjadi lokus penelitian. Hal ini berdasarkan potret kemiskinan pada wilayah Kabupaten Serang dan pemberian predikat wilayah ke tiga di Banten yang tingkat kemiskinannya rendah. Sebanyak 20 dari 326 desa di Kabupaten Serang masih masuk kategori desa tertinggal. Berdasarkan aspek sosial, di samping tingkat perekonomian masyarakat masih rendah. (Sumber Dinas Pemberdayaan Manusia dan Desa (DPMD) Kabupaten Serang 2017), dan sebanyak 12.700 rumah tidak layak huni (RTLH), serta terdapat 1.632 gedung sekolah rusak.

Berikut ini merupakan data terkait Jumlah Penduduk Miskin di Kabupaten Serang

\section{Tabel 1}

Jumlah Penduduk Miskin di Kabupaten Serang

\begin{tabular}{|r|l|r|r|r|}
\hline \multirow{2}{*}{ No } & \multirow{2}{*}{ Kabupaten/Kota } & \multicolumn{3}{|c|}{ Tahun } \\
\cline { 3 - 5 } & & 2015 & 2016 & 2017 \\
\hline 1 & Kabupaten Serang & 74,85 & 67,92 & 69,1 \\
\hline
\end{tabular}

Sumber Banten dalam Angka 2017

Dari tabel diatas menjabarkan terkait persentase jumlah penduduk miskin di Kabupaten Serang pada tahun 2015 sampai dengan tahun 2017. Dari data diatas, diketahui bahwa: Kabupaten Serang mengalami penurunan pada tahun 2016 yaitu 6,92 dari tahun 2015 dan mengalami kenaikan pun terjadi pada tahun 2017 yaitu 1,18 dari tahun sebelumnya. Dapat disimpulkan dari hasil diatas bahwa tiap tahunnya, ada penurunan dan penaikan jumlah penduduk miskin di Kabupaten Serang.

Menurut data Badan Pusat Statistik (BPS) Banten, pada tahun 2016 penduduk miskin di Kabupaten Serang berjumlah 67,92 ribu jiwa. Jika dipersentasikan sebesar 4,58 persen. Sedangkan pada 2017 tidak ada perubahan sedikit pun. Bahkan pada 2018, penduduk miskin di Kabupaten Serang meningkat menjadi 69,11 jiwa. Dengan persentasi sebesar 4,63 persen dari jumlah keseluruh penduduk. Jadi peningkatan penduduk miskin selama 3 tahun terakhir sebesar 1.190 jiwa, dengan presentasi 0,05 persen. Berikut ini data terkait angka partisipasi jenjang pendidikan di Kabupaten Serang

Tabel 2. Persentase Penduduk 15 Tahun Ke Atas

Menurut Tingkat Pendidikan yang Ditamatkan

di Kabupaten Serang Dalam Bentuk Perssentase

\begin{tabular}{|c|c|c|c|}
\hline $\begin{array}{c}\text { Ijazah/ STTB yang } \\
\text { dimiliki }\end{array}$ & Laki laki & Perempuan & jumlah \\
\hline
\end{tabular}


Volume 1 Issue 1, April 2019

http://hk-publishing.id/ijd-demos

\begin{tabular}{|c|r|r|r|} 
tidak punya Ijazah SD & 15,67 & 22,27 & 18,97 \\
\hline SD/Paket A & 38,86 & 38,48 & 38,67 \\
\hline SLTP/Paket B & 17,24 & 16,29 & 16,765 \\
\hline SMA/Paket C & 18,66 & 15,91 & 17,285 \\
\hline SMK/MA & 5,3 & 2,71 & 4,005 \\
\hline
\end{tabular}

Sumber Susenas Kabupaten Serang 2017

Partisipasi sekolah pada akhirnya turut mempengaruhi jenjang pendidikan yang ditamatkan oleh penduduk. Data diatas secara garis besar mengambarkan terkait rendahnya partisipasi penamatan pendidikan berdasarkan jenis kelamin, ketidak pemilikan Ijazah pada perempuan sebesar 22,27 persen, dapat disimpulakan tingkat partisipasi penampatan jenjang pendidikan dan pendidikan perempuan lebih rendah daripada laki-laki. Rendahnya tingkat pendidikan perempuan, akan berimbas pada kurangnya keterampilan yang dimiliki. Kurangnya keterampilan akan menyulitkan mereka untuk mencari pekerjaan atau membuka usaha/indisutri rumah, sehingga akan memperbesar atau menjadi penyumbang angka kemiskinan pada lingkup keluarga. Berikut ini merupakan tabel terkait jumlah keluarga dengan status tahapan Keluarga sejahtera pada tingkat kabupaten. Adapun datanya sebagai berikut:

Tingkat kemiskinan dan tingkat pendidikan yang rendah, mengakibatkan tidak terwujudnya masyarakat yang sejahtera makmur dan berdaya. Dan untuk mengurangi dampak sekaligus meningkatkan pembangunan dan pemberdayaan sumber daya manusia di Banten, maka program P2WKSS harus dilaksanakan dengan baik dan terstruktur. Evaluasi dan penilaian merupakan faktor yang harus dicermati oleh pemerintah dalam melaksanakan program P2WKSS ini. Dibawah ini merupakan informasi terkait desa binaan dari tahun 2009 hingga tahun 2017. Pemilihan Kabupaten Serang, sebagai lokasi penelitian diambil berdasarkan faktor potret kemiskinan. Disampaikan pada awal bahwa ada 20 dari 326 desa di Kabupaten Serang masih masuk kategori desa tertinggal (Sumber Dinas Pemberdayaan Manusia dan Desa (DPMD) Kabupaten Serang 2017), dan sebanyak 12.700 rumah tidak layak huni (RTLH), serta terdapat 1.632 gedung sekolah rusak.

Selain itu juga menurut data Badan Pusat Statistik (BPS) Banten, pada tahun 2016 penduduk miskin di Kabupaten Serang berjumlah 67,92 ribu jiwa dan pada tahun berikutnya tidak ada perubahan sedikit pun. Bahkan pada 2018, penduduk miskin di Kabupaten Serang meningkat menjadi 69,11 jiwa. Jadi peningkatan penduduk miskin selama 3 tahun terakhir sebesar 1.190 jiwa, dengan presentasi 0,05 persen.

Untuk tahun 2017 sendiri, Desa atau Kelurahan yang terpilih untuk wilayah Kabupaten Serang adalah Desa Sangiang dan Desa Bale Kencana Kecamatan Mancak berdasarkan kententuan dari Surat Keputusan Bupati Kabupaten Serang mengenai Desa/Kelurahan binaan, No.463/Kep.115-Huk.Org/2017. Adapun faktor terpilihnya Desa Sagiang dan Desa Bale Kencana ialah dikarenakan dua desa tersebut berada pada kategori 3 R, yaitu Rawan Pendidikan, Rawan Ekonomi, dan Rawan Kesehatan. Angka partisipasi pendidikan di Desa Bale Kencana dimayoritasi oleh lulusan SD, yaitu 
berkisar 1180 lulusan. Begitu pun di Desa Sagiang, angka partisipasi pendidikan di tingkat SD sebesar 980 lulusan.

Peneliti memfokuskan pada tahun 2017. Hal ini karena, tahun 2017 menjadi tahun terakhir dalam sistem penilaian. Mengutip dari artikel berita Serang disebutkan bahwa Program P2WKSS berbeda dengan tahun sebelumnya, dimana tahun sebelumnya P2WKSS dinilai setiap tahun, sedangkan mulai tahun 2018 penilaian P2WKSS dilaksanakan setiap 2 (dua) tahun sekali. Dengan demikian pelaksanaan penilaian P2WKSS akan dilaksanakan pada tahun 2019.

Terkait jumlah penduduk berdasarkan jenis kelamin di Kecamatan Mancak pada tahun 2016. Dapat diketahui bahwa jumlah penduduk pria di desa Sangaing sekitar 1482 jiwa dan jumlah penduduk perempuan 1430 jiwa. Dan jumlah penduduk pria di desa Bale Kencana berkisar 791 jiwa, dan untuk jumlah penduduk perempuannya sendiri yaitu berkisar 778 jiwa.

Keterkaitan antara jumlah penduduk laki-laki dengan jumlah penduduk perempuan dengan Program P2WKSS ialah, bahwa semakin besar kemungkinan untuk memberdayakan kaum perempuan. Seperti yang diketahui bahwa, perempuan merupakan agen pembangunan dalam lingkup keluarga. Dengan jumlah yang tidak kalah dengan kaum laki-laki, ini menjadi tugas serta potensi yang bagus. Tugas untuk dapat memberdayakan. Potensi untuk dikembangkan.

Pelaksanaan Program Terpadu P2WKSS di Desa Sangiang dan Desa Bale Kencana memiliki ketentuan dan sasaran perempuan berusia produktif 15-64 tahun. Dengan jumlah sasaran 100 KK. Warga binaan yang menjadi sasaran yakni memiliki kesejahteraan hidup, pendidikan dan keterampilan yang masih rendah atau keluarga dalam kategori Pra Sejahtera dan Keluarga Sejahtera Tahap I. Jumlah KK di Desa Sagiang 740 dan Bale Kencana 623

Dalam data yang diperoleh ada sekitar $126 \mathrm{KK}$ yang termasuk keluarga miskin di Desa Bale Kencana, dan pada Desa Sagiang ada 300 KK yang masuk dalam kategori keluarga pra Sejahtera. Dibawah ini ialah data terkait tingkat pendidikan di Desa Sagiang dan Bale Kencana. Untuk wilyah Desa Sagiang Pada tingkat SD, berikasar 980 lulusan, lalu pada tingkat SLTP berkisar 350 lulusan, dan pada tingkat SLTA berkisar 224 lulusan, untuk tingkat Diploma berkisar 34 lulusan, Sarjana berkisar 30 lulusan, dan pada tingkat Pasca Sarjana berjumlah 1 lulusan.

Untuk wilayah Desa Bale Kencana, pada tingkat SD berkisar 1180 lulusan, untuk SLTP berkisar 592 lulusan, serta pada tingkat SLTA berkisar 492 lulusan, dan pada tingkat Sarjana berkisar 20 lulusan. Adapun terkait mata pencaharian warga Desa Sangiang ialah sebagai berikut: PNS berjumlah 30 orang, buruh tani berjumlah 640 orang, dagang berjumlah 250 orang, dan lainya berjumlah 219 orang. Sedangkan mata pencaharian warga Desa Bale Kencana ialah sebagai berikut: PNS berjumlah 5 orang, buruh berjumlah 102 orang, dagang berjumlah 25 orang, petani berjumlah 809 orang, dan lainya berjumlah 23 orang. 
Berikut dibawah ini merupakan data terkait kegiatan Program P2WKSS di Desa Bale Kencana dan Desa Sangiang oleh Dinas Tenaga Kerja dan Transmigrasi Kabupaten Serang. Program pembinaan dan Penempatan Tenaga Kerja

\section{Tabel 3}

\section{Program P2WKSS oleh Disnaketrans}

\section{di Desa Bale Kencana dan Desa Sangiang}

\begin{tabular}{|c|l|l|c|}
\hline No & Dinas & Program Kegiatan & ket \\
\hline \multirow{2}{*}{1} & Disnakertrans & $\begin{array}{l}\text { Pelatihan Menjahit } \\
\text { (20 Orang) }\end{array}$ & \begin{tabular}{c} 
Desa Bale Kencana \\
\cline { 3 - 4 }
\end{tabular} \\
\hline
\end{tabular}

Sumber DKBPPA Kab. Serang 2017

Rencana Kerja Dinas Tenaga Kerja Dan Transmigrasi Kabupaten Serang pada Program P2WKSS Tahun 2017 di Kecamatan Mancak adalah memberikan pelatihan kepada penerima program. Pelatihan di ikuti oleh 20 orang dari tiap masing-masing desa.

Berdasarkan hasil observasi awal, peneliti menemukan permasalahan terkait Program Pelatihan yang diberikan Dinas Tenaga Kerja dan Transmigrasi Kabupaten Serang tahun 2017 di Kecamatan Mancak

Permasalahan Pertama, Tujuan dilaksanakan program pelatihan yaitu untuk meningkatkan keterampilan dalam rangka mengatasi permasalahan kemiskinan, namun pada pelaksanaannya tidak ada tersalurkannya penerima program baik di bukakan lapangan pekerjaan dengan perusahaan maupun industri. Tidak ada kelanjutan setelah pelaksanaan program pelatihan.

Permasalahan Kedua, hasil yang diperoleh penerima program saat mengikuti program pelatihan belum maksimal. Keterampilan yang dimiliki belum cukup untuk membuka usaha sendiri maupun bekerja pada perusahaan. Kegiatan pelatihan yang dilakasanakan selama 25 hari dirasa tidak maksimal, karena untuk belajar menjahit dibutuhkan waktu cukup lama. Selain itu terkendala pula dalam hal modal. Selain itu, mesin jahit yang dipelajari pada saat pelatihan hanya mesin jahit biasa dan terbatas, sehingga kemampuan para peserta pun terbatas, yang pada akhirnya tidak dapat memenuhi pesanan jasa menjahit. Selain itu, beberapa mesin jahit yang diberikan oleh Disnakertrans rusak karena penggunaan yang kurang baik dan minimnya pengawasan. Selesainya pelatihan selesai pula kegiatan.

\section{Kerangka Teori}

\section{Evaluasi Kebijakan}

Menurut jones dalam Agustino (2016:165) mengungkapkan evaluasi adalah suatu aktivitas yang dirancang untuk menimbang manfaat program dalam spesifikasi 
kriteria, teknik pengukuran, metode analisis dan bentuk rekomendasi. Salah satu model Evaluasi ialah Model Evaluasi wiliam Dunn dalam Nugroho (2008:473), seperti dibawah ini:

Tabel 4. Kriteria Evaluasi

\begin{tabular}{|l|l|}
\hline \multicolumn{1}{|c|}{ Kriteria } & \multicolumn{1}{|c|}{ Penjelasan } \\
\hline Efektivitas & Apakah hasil yang diinginkan telah tercapai \\
\hline Efisiensi & $\begin{array}{l}\text { Seberapa banyak usaha diperlukan untuk mencapai hasil yang } \\
\text { diinginkan }\end{array}$ \\
\hline Kecukupan & Seberapa jauh hasil yang tercapai dapat memecahkan masalah \\
\hline Pemerataan & $\begin{array}{l}\text { Apakah biaya dan manfaat didistribusikan merata kepada } \\
\text { kelompok-kelompok yang berbeda }\end{array}$ \\
\hline Responsitivas & $\begin{array}{l}\text { Apakah hasil kebijakan memuat prefensi atau nilai kelompok } \\
\text { dan dapat memuaskan mereka }\end{array}$ \\
\hline Ketepatan & \begin{tabular}{l} 
Apakah hasil yang dicapai benar-benar berguna atau bernilai \\
\hline
\end{tabular} \\
\hline
\end{tabular}

Sumber : Nugroho (2008)

\section{Metode Penelitian}

Pada penelitian kali ini, penulis menggunakan jenis penelitian Kualitatif dengan metode Deskriptif. Penelitian kualitatif mengkaji perspektif partisipan dengan strategistrtegi yang bersifat interaktif dan fleksibel. Penelitian kualitatif ditujukan untuk memahami fenomena-fenomena sosial dari sudut pandang partisipan. Teknik pengumpulan data yang dilakukan oleh penelitian ini adalah wawancara, observasi, dan dokumentasi yang bersumber dari Buku Sugiyono (2010). Adapun dalam penelitian ini, peneliti menggunakan Triangulasi Sumber sebagai metode dalam menguji keabsahan data.

\section{Hasil dan Diskusi}

Pada pembahasan ini, peneliti hanya akan memfokuskan pada pemberian Pelatihan oleh Dinas Tenaga Kerja dan Transmigrasi Kabupaten Serang Tahun 2017 Di Kecamatan Mancak kepada penerima Program. Adapun teori yang digunakan dalam penelitian ini adalah teori evaluasi menurut William N Dunn dalam Nugroho (2008) dengan indikator yaitu: Efektivitas, Efisiensi, Kecukupan, Pemerataan, Responsivitas, Ketepatan. Berikut peneliti paparkan pembahasannya. 


\section{Efektivitas}

Efektivitas berkenaan dengan suatu alternative mencapai hasil (akibat) yang diharapkan, atau mencapai tujuan dari diadakannya tindakan. Yang secara dekat berhubungan dengan rasionalitas teknis, selalu diukur dari unit produk atau layanan atau nilai moneternya. Hasil temuan lapangan, pelaksanaan program P2WKSS Tahun 2017 di Desa Sangiang dan Desa Bale Kencana, di Kecamatan Mancak, Kabupaten Serang belum cukup efektif. Ditemukan bahwa ketidakcapaian hasil nyata pasca selesainnya.

Dari pemaparan Bapak Eman, beliau menyatakan bahwa program P2WKSS merupakan salah satu program pembangunan, terutama pembangunan masayarakat desa/Kelurahan. Dimana para wanita sebagai penggeraknya. Beliau pun mengungkapkan bahwa tujuan P2WKSS adalah untuk meningkatkan sumber daya manusia dan sumber daya alam serta lingkungan agar terwujud keluarga sehat, sejahtera dan bahagia. Menelisik dari tujuan yang disampaikan oleh narasumber, kita menemukan garis besar dari adanya program P2WKSS tersebut, yaitu meningkatkan taraf hidup masyarakat penerima program.

Seperti yang telah disebutkan diatas bahwa apabila setelah pelaksanaan kegiatan kebijakan publik ternyata dampaknya tidak mampu memecahkan permasalahan yang tengah dihadapi masyarakat, maka dapat dikatakan bahwa suatu kegiatan kebijakan tersebut telah gagal (Hikmawan \& Hidayat, 2016). Adapun permasalah yang menjadi dasar utam dari dua desa ini ialah meningkatkan kreativitas serta motivasi guna menstimulus keinginan untuk meningkatkan taraf hidup masing-masing warga. Dikatakan juga bahwa adakalanya suatu kebijakan publik hasilnya tidak langsung efektif dalam jangka pendek, tetapi setelah melalui proses tertentu.

Pada dasarnya, pelatihan yang diberikan merupakan langkah baik dalam mengubah suatu kondisi masyarat baik dari aspek ekonomi, sosial dan lain sebagainya. Akan tetapi jangka waktu bimbingan serta pelatihan yang diberi, tidaklah cukup untuk dapat memberikan konsistensi mereka dalam berkelanjutan. seperti yang disampaikan oleh penerima program bahwa setelah berakhirnya kegiatan, mereka tidak lagi berkegiatan atau berusaha membuka usaha. Setelah masa satu tahun kegiatan P2WKSS berakhir, kondisi masayarakat penerima program tidak mengalami kemajuan. Hal ini dikarenakan masyarakat masih bersifat pasif dan belum termovitasi. Selain belum termovitasinya, masyarakat pun belum diberi pengarahan, bagaimana berwirausaha secara mandiri, hal ini dikarenakan kemampuan memproduksi yang kurang, dan infromasi terkait bagiamana memasarkan produk.

Adapun faktornya ialah, masayarakat tidak tidak terfasilitasi, baik dicarikan market, dan sasaran customer. Lalu tidak adanya pendampingan dalam mengurus surat izin usaha. Sehingga masyarakat kurang berkembang, dan tidak mampu mendirikan ekonomi kreatif yang mandiri. Hal tersebut dapat menjadi bukti bahwa belum cukup efektifnya program P2WKSS di Desa Sangiang dan Desa Bale Kencana, Kecamatan Mancak, Kabupaten Serang ini. Pelaksanaan program P2WKSS yang belum 
mencapai hasil yang diharapkan, berimbas kepada tujuan yang diharapkan, yaitu untuk mengentaskan kemiskinan pada penerima program yang mengalami permasalahan dalam kriteria rawan ekonomi. Seperti penjelasan pada teori evaluasi, bahwa efektivitas dapat dilihat dari seberapa jauh tujuan program ini tercapai.

Apabila setelah pelaksanaan kegiatan kebijakan publik ternyata tidak mampu memecahkan permasalahan yang tengah dihadapi masyarakat, maka dapat dikatakan bahwa suatu kegiatan kebijakan tersebut telah gagal. Program P2WKSS menempatkan kaum perempuan bukan tanpa alasan, melaian guna memberi ruang atau kesempatan pada kaum perempuan untuk dapat berkontribusi pada pembangunan. Seperti yang disampaikan oleh Bapak Eman, Wanita punya peranan yang cukup penting dalam mewujudkan keluarga sejahtera, karena wanita/ ibu mempunyai banyak waktu bersama keluarga, sehingga dapat memberi dampak positif dalam keluarga.

Dinas Tenaga Kerja dan Transmigrasi Kabupaten Serang, selaku dari salah satu penyelenggara kegiatan pada program P2WKSS di Kecamatan Mancak, memberikan pelatihan menjahit pada 40 penerima program dari 2 desa binaan terpilih. Pada indikator ini, kita melihat sejauhmana keberhasil dari program pelatihan yang diberikan. Adapun tujuan dari program ini ialah meningkatkan keterampilan penerima program P2WKSS, sehingga mampu mensejahterakan diri meraka maupun keluarganya. Pihak Dinas yaitu Ibu Irma Herlina selaku Kasi Perluasan Kesempatan Kerja mengungkapkan bahwa pelatihan menjahit yang diberikan untuk nantinya mereka bisa menjual hasil produksinya sendiri. Salah satu tujuan khsuus dari program P2WKSS ialah meningkatkan pengetahuan dan keterampilan perempuan dalam usaha ekonomi produktif untuk meningkatkan mutu hidup dan kehidupan keluarga.

Terntunya pada pelatihan keterampilan ini, bahwa program pelatihan sudah mencapai tujuan yang diharapkan, namun tidak menyelasaikan permasalahan penerima program.

\section{Efisiensi}

Menurut Willian Dunn Efisiensi berkenaan dengan jumlah usaha yang diperlukan untuk menghasilkan tingkat efektivitas tertentu. Efisiensi biasanya ditentukan melalui perhitungan biaya per unit produk atau layanan. Kebijakan yang mencapai efektivitas tertinggi dengan biaya terkecil dinamakan efisien. Kriteria efisien berarti bagaimana suatu organisasi dapat mencapai tujuan yang diharapkan dengan biaya dan waktu yang minim. Selama pelaksanaan kegiatan, dapat dikatakan bahwa program ini hanya berlangsug 1 tahun saja. Yaitu Januari hingga sampai Desember 2017.

Dalam kurun waktu satu tahun akankah mampu menyelesaikan masalah kemiskinan dan mencapai tujuan yang diharapkan, serta pada indikator ini kita akan mengetahui usaha-usaha yang dilakukan tiap dinas yang terkait dalam mewujudkan tujuan yang telah ditetapkan. Dari pemaparan hasil wawancara, diketahui bahwa keseluruhan SKPD yang tergabung dalam Pokja hanya berfokus pada meningkatkan keterampilan masyarakat penerima program. 
Memfokuskan pada pelatihan mengakibatkan kurangnya sosialisasi pada penyampaian tujuan utama. Pada hasil temuan diketahui bahwa melakukan rapat sosialisasi dengan peserta terdiri dari OPD, TP-PKK,GOW, yang tergabung dalam pokja P2WKSS. Sosialisasi hanya pada OPD, TP-PKK,GOW, yang tergabung dalam pokja P2WKSS, utamanya adalah pemberian sosialisasi pada penerima program. Sosialisasi merupakan langkah pertama dalam pelaksanaan suatu program. Adapun proses sosialisasi sangat berpegaruh terhadap keberlanjutan dari suatu program. dalam proses sosialisasi seorang fasilitator harus sangat berhati-hati, serta mempertimbangkan kondisi masyarakat baik tingkat pendidikan, karakter, daya terima dan pemahaman masyarakat. Dalam proses sosialisasi setidaknya melakukan sosialisasi terkait personal maksud dan tujuan datang ke wilayah tersebut, kemudian melakukan sosialisasi tentang lembaga dan program.

Pada prosesnya, sosialisasi terbagi atas dua metode, yaitu sosialisai langsung yang dilakukan secara langsung oleh fasilitator kepada masyarakat. Metode ini paling efektif karena akan berhadapan langsung dan memberikan penjelasan terperinci terkait program. Serta yang kedua ialah metode sosialisasi tidak langsung, yaitu melalui perantara. Contoh metode tersebut adalah meminta bantuan aparat desa, tokoh masyarakat, atau salah satu warga untuk mensosialisasikan program kepada masyarakat, tanpa didampingi oleh fasilitator.

Dalam pelaksanaan Program P2WKSS di Desa Sangiang dan Bale Kencana, sosialiasi yang digunakan ialah dengan metode tidak langsung, metode ini mungkin efisien dalam segi waktu, akan tetapi kurang menjamin dari segi hasil karena masyarakat tidak mendapatkan informasi langsung dari sumbernya. sosialisasi harus dilakukan dengan tepat dan benar karena hal tersebut merupakan langkah awal yang sangat menentukan pelaksanaan program.

Diketahui bahwa bentuk usaha sosialisasi dilakukan lebih banyak oleh perangkat desa yaitu perangkat PKK. Hal ini terjadi, mengingat kedekatan pengurus PKK dengan warga, dirasa mampu membantu. Akan tetapi tugas sosialisasi utamanya merupakan tugas dari leading sektor dan jajaran OPD yang tegabung dalam Pokja. Dari hasil pemaparan diatas, peneliti dapat menarik bahwa efisiensi program dan usaha-usaha yang dilakukan untuk pencapaian tujuan masih kurang optimal. Hal ini terlihat, dari kurang berkembangnya penerima program, karena mereka hanya mengetahui bagaimana membuat, tanpa diarahkan untuk mencoba berpikir penjualan. Serta, sosialisasi program yang kurang dilakukan, sehingga mereka hanya tahu bahwa ini hanya pelatihan, tanpa dalam mengetahui tentang tujuan yang sebenarnya.

Menjadi menarik, bahwa menurut pihak dinas, tujuan telah tercapai. Hal ini menurut mereka berdasarkan hasil penilaian yang mereka lakukan. Bila dikaitkan dengan rumusan masalah pertama, yaitu tidak adanya keberlanjutan atau kontroling dari pihak dinas maupun perangkat desa, ialah merupakan perihal ketidakinginan untuk mengeluarkan anggaran kembali. Program ini hanya program kerja yang harus diselesaikan, bukan menjadi pemecah permasalahan kemiskinanan di lingkup 
keluarga. Diketahui bahwa idealnya sebuah program diimplementasikan selama 5 tahun agar mencapai tujuan yang telah ditetapkan.

Pada pelatihan menjahit yang diberikan oleh Dinas Tenaga Kerja dan Transmigrasi Kabupaten Serang. Pada indikator ini jelas bahwa disebutkan seberapa banyak usaha yang diperlukan untuk mencapai hasil yang diinginkan. Dalam pelaksanaanya usaha yang dilakukan oleh Dinas Tenaga Kerja dan Transmigrasi Kabupaten Serang ialah memberikan pelatihan selama 25 Hari, dengan Intensitas waktu selama kurang lebih 6 jam. Penerima pelatihan dibagi menjadi 5 kelompok, terdiri dari 4 warga. Dengan fasilitas masing-masing satu mesin jahit perkelompok, pada pelatihannya, penerima program diberi materi yang telah disesuaikan dengan kebutuhan, adapun materi yang terbagi sebagai berikut:

Tabel 5. Pelatihan Menjahit

\begin{tabular}{|c|l|c|c|c|}
\hline \multirow{2}{*}{ No } & \multicolumn{2}{|c|}{ Mata Pelatihan } & \multicolumn{3}{c|}{ Waktu Pelatihan } \\
\cline { 3 - 5 } & & Teori & Praktek & Jumlah \\
\hline 1 & Pengetahuan Mesin Dan Alat & 4 & & 4 \\
\hline 2 & Membaca Sketsa Dan Model & 8 & & 8 \\
\hline 3 & $\begin{array}{l}\text { Cara Mengambil Ukuran } \\
\text { Tubuh }\end{array}$ & 4 & & 4 \\
\hline 4 & Mengambar Pola & 8 & 17 & 25 \\
\hline 5 & Menjahit & 31 & 105 & 136 \\
\hline 6 & Memotong Bahan & 2 & 13 & 15 \\
\hline
\end{tabular}

Sumber : Dinaskertrans Kabupaten Serang 2017

Pada tabel diatas, kita mengetahui bahwa porsi pemberian materi dan praktik telah sesuai, yaitu memberikan porsi waktu yang banyak pada bidang praktik. Adapun untuk materi pembelajaran, penerima program mendapatkan pelatihan berupa membuat baju kemeja, baju koko, celana dan sebagainya. Dinas Tenaga Kerja dan Transmigrasi Kabupaten Serang, berfokus pada meningkatakan keterampilan. Pemberian pelatihan yang hanya berlangsung selama 25 hari, tidak dapat memberikan hasil maksimal, ditambah masyarakat yang tidak ada keinginan untuk berkembang, sehingga kemampuan atau ilmu yang diberi akan berangsur mengurang. Umunya pelatihan menjahit, diberi selama kurang lebih 3 bulan lamanya. Memang pada kasus Program P2WKSS, jangka waktu hanya berkisar 1 Bulan.

\section{Kecukupan}

Berkenaan dengan seberapa jauh suatu tingkat efektivitas memuaskan kebutuhan, nilai, atau kesempatan yang menumbuhkan adanya masalah. Kriteria kecukupan menekankan pada kuatnya hubungan antara alternatif kebijakan dan hasil yang diharapkan. Peneliti ingin mengetahui apakah program P2WKSS ini dapat mencapai hasil yang diharapkan dengan sumber daya yang ada.

Meninjau dari pencapaian sasaran tertentu dengan biaya tertentu. Pada pelaksanaan Program P2WKSS di Mancak. Program ini mentargetkan 100KK untuk 
dibina. Dalam pencapaianya, diketahui bahwa pencapaian sasaran (3R), yaitu Rawan Ekonomi, Rawan Pendidikan dan Rawan Kesehatan, sudah dapat mecapai sasaran yang ditentukan. Jangkauan jumlah target sasaran program tidak mampu lebih dari 100 KK pada tiap pelatihan yang ada. Hal ini berarti bahwa pencapaian sasaran dengan biaya tertentu, sudah dapat dikatakan sesuai dengan anggaran yang dimiliki. Jika kita melihat dari sudut padangan biaya, dimana biaya atau anggaran yang dimiliki tidaklah banyak.

Seperti yang diketahui bahwa jumlah sasaran ialah 100KK, sehingga menimbulkan permasalahn yaitu ketika dalam lokasi program terdapat lebih dari 100KK, sehingga memunculkan kecemburuan sosial di dalam masyarakat. Desa Sangiang Khususnya warga kampung pasir gadung terdapat $300 \mathrm{KK}$, hal ini tentunya menjadi tantangan baik bagi pelaksana kegiatan, leading sektor serta perangkat desa. Dimana tentunya merasa harus mampu memilah dan menentukan warga mana yang layak menerima program. Berkaitan dengan kecemburaan yang timbul pada lingkup masyarakat yang tidak bergabung menjadi penerima program pihak kelurahan hanya mampu memberi pengertian. Pada praktiknya, disebutkan bahwa:

\section{Tabel 6. Program P2WKSS oleh Disnaketrans}

di Desa Bale Kencana dan Desa Sangiang

\begin{tabular}{|c|l|l|c|}
\hline No & Dinas & Program kegiatan & Ket \\
\hline 1 & Disnakertrans & $\begin{array}{l}\text { Pelatihan Menjahit } \\
\text { (20 Orang) }\end{array}$ & Desa Bale Kencana \\
\cline { 4 - 4 } & & Desa Sagiang \\
\hline
\end{tabular}

SumberDKBPPA Kab. Serang 2017

Dari tabel diatas kita mengetahui bahwa penerima program pelatihan hanya 20 warga dari masing-masing desa. 20 warga penerima program, dengan latar belakang pendidikan yang berbeda. Diketahui bahwa kriteria kecukupan menekankan pada kuatnya hubungan antara alternatif kebijakan dan hasil yang diharapkan. Maksud dari alternative kebijakan ialah, ketika pemilihan penerima program berada pad akisaran 20 warga, dan hasil yang diharapkan ialah 20 warga tersebut merupakan sasaran program yang telah ditentukan. Diketahui bahwa sasaran target ialah mereka yang berada pada Rawan Pendidikan, Rawan Ekonomi serta Rawan Kesehatan.

Pada tabel dibawah ini, kita dapat mengetahui tingkat pendidikan dari penerima program.

Tabel 7 Daftar Peserta Pelatihan Menjahit

\begin{tabular}{|r|l|c|}
\hline \multicolumn{3}{|c|}{ Desa Sagiang } \\
\hline No & \multicolumn{1}{|c|}{ Nama } & $\begin{array}{c}\text { Tingat } \\
\text { Pendidikan }\end{array}$ \\
\hline 1 & Hayanah & SD \\
\hline 2 & Sri Supriyanti & MA \\
\hline 3 & Nurdianah & SLTP \\
\hline
\end{tabular}

\begin{tabular}{|r|l|c|}
\hline \multicolumn{3}{|c|}{ Desa Bale Kencana } \\
\hline No & \multicolumn{1}{|c|}{ Nama } & $\begin{array}{c}\text { Tingat } \\
\text { Pendidikan }\end{array}$ \\
\hline 1 & Bayinah & SLTP \\
\hline 2 & Mariah & SMK \\
\hline 3 & Sarnati & SLTP \\
\hline
\end{tabular}




\begin{tabular}{r|l|c|}
4 & Marfuah & SD \\
\hline 5 & Siti Masirah & SD \\
\hline 6 & Atun Alawiah & SLTP \\
\hline 7 & Tijah & SD \\
\hline 8 & Siti Julaehah & SLTP \\
\hline 9 & Jazilatul & SLTP \\
\hline 10 & Nurheti & SD \\
\hline 11 & Yuyun & SD \\
\hline 12 & Nurjanah & SD \\
\hline 13 & Lusiana & SLTP \\
\hline 14 & Ida Nuraida & SLTA \\
\hline 15 & Masfuah & SLTP \\
\hline 16 & Alawiyah & SLTP \\
\hline 17 & Masiti & SD \\
\hline 18 & Mastukah & SD \\
\hline 19 & Devi Risnayah & SLTP \\
\hline 20 & Iroh & SLTP \\
\hline
\end{tabular}

\begin{tabular}{|r|l|c|}
4 & Napsiah & SD \\
\hline 5 & Jubaedah & SLTA \\
\hline 6 & Rohayati & SLTP \\
\hline 7 & Hayati & SD \\
\hline 8 & Marwita & SMP \\
\hline 9 & Masri & SLTP \\
\hline 10 & Suheni & SD \\
\hline 11 & Putonah & SD \\
\hline 12 & Siti & SD \\
\hline 13 & Mulaehah & SLTA \\
\hline 14 & Sarkamah & SD \\
\hline 15 & Supiyah & SD \\
\hline 16 & Idaiyah & SD \\
\hline 17 & Munah & SD \\
\hline 18 & Nurlela & SD \\
\hline 19 & Jonah & SD \\
\hline 20 & Susilawati & SLTP \\
\hline
\end{tabular}

Sumber Disnaker 2017

Dari tabel diatas, kita melihat bahwa ada sekitar 50 Persen Warga dengan pendidikan SD, dan 37,5 Persen warga dengan tingkat pendidikan SLTP, lalu 7,5 persen warga dengan pendidikan SLTA, serta untuk MA dan SMK ada sekitar 2,5 persen. Dari info tersebut, kita dapat mengetahui bahwa capaian sasaran target pada indikator rawan pendidikan, telah sesuai.

\section{Pemerataan}

Kriteria ini erat hubungannya dengan rasionalitas legal dan sosial yang menunjuk pada distribusi akibat dan usaha antar kelompok-kelompok yang berbeda dalam masyarakat. Kebijakan yang berorientasi pada perataan adalah kebijakan yang akibatnya (missal, unit pelayanan atau manfaat moneter) atau usaha (misalnya biaya moneter) secara adil didistribusikan. Berdasarkan pendapat diatas, kemerataan berarti kebijakan yang dikeluarkan Perangkat Desa haruslah dapat dirasakan bagi seluruh warga penerima tanpa membedakan antara golongan atau ras (Hikmawan, 2017b). Sehingga dengan adanya kebijakan pihak akan terciptanya keadilan bagi seluruh rakyat Indonesia dan tidak ada diskriminasi.

Pada pelaksanaan P2WKSS di Kecamatan Mancak, peneliti menemukan bahwa pendistrubusiaan manfaat pada penerima program telah mereta. Hal ini terlihat dari hasil temuan bahwa dalam tiap pelatihan, baik memasak, menjahit, serta pelatihan yang lainnya, para penerima program yang terdiri dari 100KK pertiap desa, mendapat satu jenis pelatihan. Dengan jumlah pelatihan oleh dinas Kesehatan yaitu 20 orang 
permasing-masing desa, pelatihan dari Dinas Perindakop yaitu 30 orang dari masingmasing desa, lalu pelatihan dari Gow yaitu 10 orang permasing-masing desa, serta pelatihan dari Disnaker yaitu 20 orang permasing-masing desa, dan terakhir pelatihan dari Disporapar yaitu 20 orang. Pemerataan Bantuan yang didapat oleh warga penerima program dari Program P2WKSS sebenarnya sudah sesuai dengan aturan yang ditetapkan. Program ini belum menjangkau seluruh keluarga Pra Sejahtera dan keluarga sejahtera tahap I yang ada di Desa Sangiang dan Desa Bale Kencana.

Seperti yang sudah diketahui bahwa Dinas Tenaga Kerja dan Transmigrasi Kabupaten Serang, memberikan pelatihan menjahit di dua Desa peneria Program P2WKSS Tahun 2017. Pada indikator pemerataan, merajuk pada distribusi akibat dan usaha antar kelompok-kelompok yang berbeda dalam masyarakat. Kelompok yang berbeda disini ialah, warga Desa Sagiang dan Desa Bale Kencana. Kita hanya akan berfokus pada penerima program. Pada pemereataan distrubusi manfaat, diketahu bahwa, pemberian materi disamakan, baik untuk Desa Sagiang maupun Desa Bale Kencana. Dalam pemberian mesin jahit pun tentunya disamakan. Hal ini dilakukan agar terciptakanya kesamaan dan pemerataan yang bijak. Adapun materi pembelajaran yang disebutkan tadi, peneliti lampirkan kembali. Sebagai berikut:

Tabel 8. Jadwal Pelatihan Menjahit Di Desa Sagiang dan Bale Kencana

\begin{tabular}{|c|c|c|}
\hline Tanggal & Waktu & Materi \\
\hline 02-Agu-17 & $\begin{array}{l}08.00- \\
15.45\end{array}$ & Pengenalan alat uku, mengukur tubuh,membuat pola rok \\
\hline 03-Agu-17 & $\begin{array}{l}08.00- \\
15.45\end{array}$ & membuat pola besar rok,pengoparsian mesin jahit, menjahit rok \\
\hline 04-Agu-17 & $\begin{array}{l}08.00- \\
15.45\end{array}$ & menjahit rok \\
\hline 05-Agu-17 & $\begin{array}{l}08.00- \\
15.45\end{array}$ & membuat pola blus \\
\hline 07-Agu-17 & $\begin{array}{l}08.00- \\
15.45\end{array}$ & menjahit blus, Fhinising Pakaian blus \\
\hline 08-Agu-17 & $\begin{array}{l}08.00- \\
15.45 \\
\end{array}$ & membuat pola celana anak, menjahit celana anak \\
\hline 09-Agu-17 & $\begin{array}{l}08.00- \\
15.45\end{array}$ & membuat pola gaun anak, menjahit gaun anak \\
\hline 10-Agu-17 & $\begin{array}{l}08.00- \\
15.45\end{array}$ & gaun anak, finishing gaun anak \\
\hline 11-Agu-17 & $\begin{array}{l}08.00- \\
15.45\end{array}$ & membuat pola daster, menjahit daster \\
\hline 12-Agu-17 & $\begin{array}{l}08.00- \\
15.45\end{array}$ & lanjut menjahit daster \\
\hline 14-Agu-17 & $\begin{array}{l}08.00- \\
15.45 \\
\end{array}$ & Finishing daster \\
\hline 15-Agu-07 & $\begin{array}{l}08.00- \\
15.45\end{array}$ & membuat pola rok celana, menjahit rok celana \\
\hline 16-Agu-17 & $08.00-$ & menjahit rok celana \\
\hline
\end{tabular}


Volume 1 Issue 1, April 2019

http://hk-publishing.id/ijd-demos

\begin{tabular}{|c|c|c|}
\hline & 15.45 & \\
\hline 17-Agu-17 & $\begin{array}{l}08.00- \\
15.45 \\
\end{array}$ & menjahit rok celana dan finishing rok celana \\
\hline 18-Agu-17 & $\begin{array}{l}08.00- \\
15.45\end{array}$ & membuat pola kemaja, menjahit kemeja \\
\hline 19-Agu-17 & $\begin{array}{l}08.00- \\
15.45\end{array}$ & menjahit kemeja \\
\hline 21-Agu-17 & $\begin{array}{l}08.00- \\
15.45\end{array}$ & Finishing kemeja \\
\hline 22-Agu-17 & $\begin{array}{l}08.00- \\
15.45\end{array}$ & membuat pola gamis, menjahit gamis \\
\hline 23-Agu-17 & $\begin{array}{l}08.00- \\
15.45\end{array}$ & menjahit gamis, finishing gamis \\
\hline 24-Agu-17 & $\begin{array}{l}08.00- \\
15.45 \\
\end{array}$ & membuat pola baju koko, memjahit baju koko \\
\hline 25-Agu-17 & $\begin{array}{l}08.00- \\
15.45 \\
\end{array}$ & finishing baju koko, membuat pola rok setengah \\
\hline 26-Agu-17 & $\begin{array}{l}08.00- \\
15.45 \\
\end{array}$ & membuat pola rok setengah, menjahit rok setengah \\
\hline 28-Agu-17 & $\begin{array}{l}08.00- \\
15.45\end{array}$ & menjahit rok setengah \\
\hline 29-Agu-17 & $\begin{array}{l}08.00- \\
15.45\end{array}$ & menjahit rok setengah \\
\hline 30-Agu-17 & $\begin{array}{l}08.00- \\
15.45\end{array}$ & finishing, evaluasi \\
\hline
\end{tabular}

Sumber Disnakertrans 2017

Dari tabel diatas, jelas bahwa tidak adanya pembeda materi yang diberikan.

\section{Responsivitas}

Berkenaan dengan seberapa jauh suatu kebijakan dapat memuaskan kebutuhan prefensi, atau nilai kelompok-kelompok masyarakat tertentu. Kriteria responsivitas adalah penting karena analisis yang dapat memuaskan semua kriteria lainnya (efektivitas, efisiensi, kecukupan, perataan) masih gagal jika belum menanggapi kebutuhan actual dari kelompok yang semestinya diuntungkan dari adanya suatu kebijakan.

Pada pelaksanaan program P2WKSS ini, Responsivitas warga penerima program sangat antusias. Hal ini bahwa, responsivitas dari adanya program tersebut amat sangat baik. Dimana warga penerima program mampu mendapatkan keterampilan. Penerima program binaan sudah merasa cukup puas dengan adanya bantuan dan pelatihan yang diberikan. Namun ada juga yang merasa bantuan dan pelatihan ini belum cukup dan berharap adanya bantuan modal dari pemerintah, serta berharap juga dibantu pada perihal pemasarannya. Tujuan awal program ini adalah untuk pengentasan kemiskinan hingga dapat membuat penerima program untuk dapat berusaha meningkatan ekonomi agar dapat memenuhi kebutuhan hidup mereka, tetapi motivasi serta keinginan masyarakat yang rendah, membuat kondisi yang diharapakan 
tidak terwujud. Jadi seharusnya penerima program dapat membuka pikiran dan memanfaatkan program ini dengan maksimal agar dapat berfungsi dengan baik.

\section{Ketepatan}

Kriteria ini secara dekat dihubungkan dengan rasionalitas substansif, karean pertanyaan tentang ketepatan kebijakan tidak berkenaan dengan satuan kriteria individu tetapi dua atau lebih kriteria secara bersama-sama. Ketepatan merujuk pada nilai atau harga dari tujuan program dan kepada kuatnya asumsi yang melandasi tujuan-tujuan tersebut. Dari pendapat di atas maka kriteria ini dimaksud adalah sebuah penilaian terhadap pelaksanaan program atau kebijakan oleh organisasi atau pemerintah, dengan cara mengevaluasi aspek-aspek dampak kebijakan.

Pada indikator ini, peneliti melihat bahwa program P2WKSS tersebut, sangatlah bermanfaat bagi mereka warga penerima program. Dimana mereka mampu memiliki keterampilan baru, dan bisa membuka usaha. Hal ini berarti bahwa ketepatan program yang diberikan, mampu memberi ilmu dan keterampilan baru kepada warga desa Bale Kencana dan Sangiang. Pelaksana kegiatan berharap bantuan yang diberikan dapat memberikan manfaat kepada masyarakat yaitu adanya peningkatan ekonomi, sehingga warga penerima program bisa membuka usaha, serta adanya perbaikan dari aspek kesehatan. Namun untuk pencapaian tujuan tersbut belum dapat tercapai.

Usaha yang dilakukan oleh dinas terkait, memberikan dampak yang baik, khususnya pada peningkatan keterampilan. Akan tetapi dalam mengukur keberhasilan, kita perlu mementukan tidak hanya seberapa besar derajat perubahan terjadi, namun menilai apakah program pelatihan menjahit tersebut mampu berhasil dalam menyelesaikan permasalahan warga di desa tersebut. Adapun dimensi-dimensi dampak yang mampu kita analisa, berdasarakan Dimensi dampak dari kebijkan menurut Agustino (2016:188), yaitu Dimensi Subjek utama, Dimensi terhadap situasi dan kelompok lain, Dimensi waktu, Dimensi biaya.

Pertama, Dimensi Subjek utama, pada dimensi ini pertama-tama harus didefinisikan siapa yang akan terkena pengaruh kebijakan: apakah masyarakat miskin, pengusaha kecil, produsen minyak, anak sekolah, guru, atau siapa. Pada program pelatihan menjahit ini, adapun yang menjadi sasaran kegiatan ialah mereka yang masuk dalam kategori 3 R (Rawan Pendidikan, Rawan Ekonomi dan Rawan Kesehatan). Berdasarkan hasil temuan lapangan diketahui bahwa sekitar 50 persen penerim program ialah mereka yang berpendidikan terendah yaitu SD, dengan sumber penghasilan dari satu pihak (suami), dan sumber berdagang. Dengan kata lain, sasaran terdefinisikan ialah masyarakat miskin. Dalam point ini perlu kiranya ditentukan dampak kebijakan yang dimaksud. Dampak yang ditentukan oleh Dinas terkait ialah agar meningkatkan kesempatan kerja pada mereka dan mampu membangun ekonomi kreatif.

Kedua, dimensi terhadap situasi dan kelompok lain; atau yang dapat disebut juga dengan eksternalitas atau Spill-Over effect. Pada dimensi ini berbicara terkait dampak adanya program terhadap pihak atau kelompok diluar sasaran program dan kelompok 
sasaran. Pada keseluruhan pelaksanaan kegiatan P2WKSS, diketahui bahwa ada sekitar 300KK di Desa Sagiang yang terdata berada pada lokasi binaan, dan 126 KK di Desa Bale Kencana. Seperti yang kita ketahui bahwa, program P2WKSS tersebut hanya mengambil kuota sebanyak 100 KK. Sehingga berdampak pada timbulnya kecemburuan sosial.

Untuk program pelatihan menjahit sendiri, pada dasarnya tidak berpengaruh kepada kelompok diluar kelompok binaan pelatihan menjahit, hal ini dikarenakan mereka (100KK) mendapatkan pelatihan yang berbeda. Pelatihan dari Dinas Perindakop yaitu 30 orang dari masing-masing desa, lalu pelatihan dari Gow yaitu 10 orang permasing-masing desa, serta pelatihan dari Disnaker yaitu 20 orang permasingmasing desa, dan terakhir pelatihan dari Disporapar yaitu 20 orang. Pemerataan Bantuan yang didapat oleh warga penerima program dari Program P2WKSS sebenarnya sudah sesuai dengan aturan yang ditetapkan.

Ketiga, Dimensi waktu, pada dimensi pertanyaan yang sering muncul dalam konteks ini ialah: apakah kebijakan dibuat untuk situasi jangka menengah, jangka pendek, atau jangka panjang. Pada pelaksanaan kegiatan P2WKSS diketahui bahwa Program ini berlangsung selama 1 tahun, dan untuk program pelatihan sendiri dilaksanakan hanya selama 25 hari. Dalam 25 hari, penerima program mendapat pelatihan yang sama, dengan intensitas yang sama. Namun idealnya pelatihan menjahit diberikan selama 3 bulan lama. Dengan kata lain, program ini dibentuk untuk situasi jangka pendek.

Program-program bantuan yang berorientasi pada kedermawanan pemerintah, tidak akan menyelesaikan persoalan kemiskinan, justru memperburuk moral dan perilaku masyarakat miskin, menjadikan mereka selalu bergantung kepada pemerintah tanpa harus berkerja keras untuk merubah nasib. Masyaraat akan terkena virus penyakit psikososial yait malas bekerja, fatalistic, manja, dan rasa bergantung terhadap pemerintah cukup tinggi. Kedua, Kurangnya pemahaman berbagai pihak tentang penyebaba kemiskinan itu sendiri, sehingga program kemiskinan tidak didasarkan pada isu-isu kemiskinan yang penyebabnya berbeda-beda secara local.

Ketidakberhasilan dalam pengentasa kemiskinan, selain disebabkan faktor bantuan sosial yang tidak mendidik masyarakat miskin, juga cara pemahaman bahwa kemiskinan disebabkan sebuah kondisi ekonomi tanpa mempertimbangkan aspek sosial, budaya dan politik masyarakat. Akibat dari pandangan itu, proyek pengetasan kemiskinan atau pemberdayaan masyarakat lebih berorientasi pada perbaikan peningkatan pendapatan ekonomi masyarakat.

Mengatasi kemiskinan merupakan upaya memberdayakan masyarakat untuk hidup mandiri, baik secara ekonomi, sosial budaya dan politik. Masyarakat miskin seyogyanya diberi akses yang luas untuk menjagka berbagai sumber-sumber daya yang dapat menopang kehidupan mereka. Oleh karena itu, program bantuan seharsunya difokuskan untuk menumbuhkan ekonomi produktif, dengan memberikan bantuan modal usaha tanpa anggunan pada masyarakat miskin, juga memberikan pelatihan 
keterampilan untuk menumbukan jiwa wirasuha kemandirian. Dengan demikan, secara bertahap, masyarakat membebaskan diri dari ketergantungan.

Jika kita membahas progam P2WKSS ini, apa yang dilakukan pemerintah merupakan langkah yang tepat yaitu, pemberian keterampilan. Seperti penjelasan diatas "program bantuan seharsunya difokuskan untuk menumbuhkan ekonomi produktif, dengan memberikan bantuan modal usaha tanpa anggunan pada masyarakat miskin, juga memberikan pelatihan keterampilan untuk menumbukan jiwa wirasuha kemandirian". Namun jika pada hasilnya tidak memberi dampak perubahan pada kondisi sosial, hal ini tentunya sesuai dengan penjambaran diatas, yaitu kurangnya motivasi masyarakat untuk keluar dari garis kemiskinan, serta rasa bergantung terhadap pemerintah cukup tinggi. Hal ini dibuktikan dengan pengamatan peneliti dilapangan, bahwa mereka menginginkan pihak pemerintah untuk mengawasi.

Disebutkan bahwa "Ketidakberhasila dalam pengentasa kemiskinan, selain disebabkan faktor bantuan sosial yang tidak mendidik masyarakat miskin, juga cara pemahaman bahwa kemiskinan disebabkan sebuah kondisi ekonomi tanpa mempertimbangkan aspek sosial, budaya dan politik masyarakat". Peneliti setuju perihal bahwa pemahaman pemangku kebijakan dalam membentuk suatu program pengentasan kemiskinan, seringnya mengutamakan cara pandang bahwa kemiskinan terjadi disebabkan pada kondisi ekonomi. Hal ini terbukti dengan seringnya, program pelatihan yang bertujuan meningkatkan pendapatan dan keterampilan, tanpa mempertimbangkan aspek sosial, budaya dan politik masyarakat.

Dengan hanya berorientasi pada aspek ekonomi, pemerintah hanya menciptakan sumber daya tanpa daya saing. Sama halnya dengan ulasan dari Sulistiyani (2004), beliau mengungkapkan ada lima langkah penting yang perlu diperhatikan dalam upaya pengembangan kemampuan berwirausaha bagi perempuan yaitu: Pertama, membantu dan mendorong kaum perempuan untuk membangun dan mengembangkan pengetahuan serta kompetensi diri mereka, melalui berbagai program pelatihan. Mengembangkan pengetahuan, merupakan hal utama yang perlu dipelajari, disini pengembangan pengetahuan bukan hanya sekedar mengubah kondisi sumber daya yang ada, menjadi sumber daya yang terampil. Akan tetapi hal ini juga berbicara terkait bagaimana sejauhmana pemahaman masyarakat terkait kondisi mereka, apa yang menjadi batasan mereka, serta sejauhmana mereka mengetahui permasalahanpermasalahan yang ada. Disinilah tugasnya pemerintah memberikan edukasi atau pengetahuan kepada masyarakat, agar masyarakat mampu memahami serta berpengetahuan lebih.

Kedua, membantu kaum perempuan dalam strategi usaha dan pemasaran produk. Hal ini menjadi amat sangat penting, karena kurang pahamnya penerima program akan membuat hasil keterampilan yang diberikan, tidaklah berjalan maksimal. Hanya akan menjadi sebatas ilmu tanpa pengimplemtasian. Hal ini terjadi pada temuan lapangan yang peneliti lakukan, warga penerima program P2WKSS di Mancak, dimana mereka telah diberdayakan secara keterampilan, namun mereka tidak diberi pengetahuan terkait strategi usaha dan pemasaran. Hal ini terbukti, dengan tidak 
berlanjutnya menyalurkan keterampilan yang telah dimiliki. Adapun peneliti mengambil kesimpulan, bahwa faktor penyebab tidak tersalurukannya adalah, tidaknya ada modal serta konsumen dalam pembelian produk. Ini menjadi masalah yang cukup krusial dalam membentuk usaha.

Ketiga, Memberikan pemahaman terhadap regulasi dan peraturan pemerintah terkait dengan legalitas dunia usaha. Penelit amat sangat setuju, bahwa pemerintah harus memberi pemahaman kepada masyarakat atau penerima program pelatihan terhadap regulasi dan peraturan pemerintah terkait dengan legalitas dunia usaha, agar masyarakat menjadi melek hukum. Akan tetapi pada kegiatan program P2WKSS tahun 2017 di Mancak, masyarakat hanya diberi penyampaian bahwa dalam membangun usaha perlu adanya ijin usaha, tanpa diberikan pemahaman lebih terkait regulasi dan legalitas dunia usaha. Masyarakat yang notabennya merupakan sumber daya dengan pendidikan rendah, memiliki keterbatasaan pengetahuan, seharusnya pemerintah mampu menyadari hal ini. Sebagian besar peserta pelatihan pengolahan emping aneka rasa dan pembuatan kue, tidak ada yang membuka usaha. Mereka tetap menjual olahan emping konvensional.

Keempat, Mendorong dan membantu kaum perempuan untuk mampu menggunakan tekhnologi informasi dan komunikasi secara optimal. Kemajuan teknologi di era sekarang amatlah sangat pesat. Penggunaan massif media sosial, guna menjadi media interaksi penjualan pada era sekarang sangat tinggi. Jika kita bisa memanfaatkan media ini, tidak membutuhkan modal besar, dan bisa menjual lebih luas. Dengan catatan mereka paham dan mempunyai strategi penjualan. Akan tetapi temuan dilapangan, pemerintah tidak mengunakan sosial media, atau tidak menghimbau terkait strategi penjualan dengan mengunakan media sosial. Pemerintah sekali lagi hanya fokus pada peningkatan keterampilan sumber daya. Tidak adanya edukasi perihal ini, menjadi amat sangat disayangkan.

Kelima, Membuat usaha mikro/jaringan usaha mikro perempuan/forum pelatihan usaha. Ini bisa menjadi alternatif, apabila pemahaman terkait penggunan media sosial menjadi media penjualan, disini masayarakat dapat saling memberi informasi dan pengetahuan terkait usaha. Dengan adanya jaringan usaha/Forum pelatihan, akan membuat semakin seringnya masyarakat berkreasi dan beraktivitas. Sekali lagi, bahwa pada program P2WKSS di Mancak, tidak adanya wadah penyaluran kreativitas masyarakatnya.

Melihat lima langkah penting yang perlu diperhatikan dalam upaya pengembangan kemampuan berwirausaha bagi perempuan, yang telah dipaparkan. Peneliti dapat mneyimpulkan bahwa, pemerintah belum mencapai pada tahapan tersebut, hal ini dikarenakan kurangnya pemahaman pemerintah, dan hanya berorientasi pada meningkatkan keterampilan sumber daya, tanpa memberi pengetahuan dan pemahaman terkait pengembangan usaha.

Permasalahan kemiskinan yang tejadi di wilayah Kecamatan Mancak, bervariasi. Dimana rata-rata pekerjaan mereka ialah sebagai buruh tani, dengan penghasilan perhari sekitar 60 ribu. Penghasilan ini hanya bersumber pada satu anggota keluarga. 
Terjeratnya masyarakat kedalam limbah kemiskinan tentunya bukan tanpa alasan. Sebagai mana yang dituliskan oleh Suharto (2009), faktor penyebab kemiskinan ialah antara lain:

Pertama, Faktor individual, hal ini terkait dengan kondisi fisik dan psikologis seseorang, yaitu orang menjadi miskin disebabkan oleh perilaku, pilihan, atau kemampuan dari orang miskin itu sendiri dalam menghadapi kehidupannya. Peneliti setuju dengan pernyataan tersebut, peneliti melihat masayarakat Desa Sangiang maupun Desa Bale Kencana masih sangat terjerat padangan, bahwa wanita khususnya ibu rumah tangga, hanya boleh mengerjakan pekrjaan rumah, ditambah lagi dengan padanngan bahwa kondisi tubuh kaum perempuan dianggap jauh lebih lemah, inilah mengapa lebih bnayak kaum pria yang bekrja. Sehingga lingkup aktivitas kaum perempuan hanya sebatas lingkup kecil, tidak mampu mengenal hal baru selain urusan rumah tangga.

Kedua, Faktor sosial, terkait dengan kondisi lingkungan sosial yang menyebabkan seseorang menjadi miskin seperti diskriminasi berdasarkan usia, gender, dan etnis. Dalam hal ini, seperti yang dijabarkan diatas, pandangan lemah juga bukan hanya dari kaum pria saja, namun hal ini bisa terjadi karena kaum perempuan selalu meperlihatkan bahwa mereka lemah. Inilah yang akhirnya membentuk suatu diskriminasi terjadi (Hikmawan, 2017a). Disaat satu individu berusaha berkembang, namun sayangnya padangan yang sudah tertanam lama, menjadi penghalang.

Ketiga, Faktor kultural, yaitu kondisi budaya yang menyebabkan kemiskinan seperi kebiasaan hidup. Melihat faktor ini, peneliti menarik kesimpulan berdasarkan temuan dilapangan, peneliti melihat bahwa kemiskinan merupakan warisan dari keluarga, sehingga mereka merasa biasa dan merasa tidak terlalu peduli. Kemiskinan muncul akibat perbedaan kualitas sumber daya manusia karena kualitas sumber daya manusia yang rendah berarti produktivitas dan upahnya pun rendah. adanya ketidaksamaan pola kepemilikan sumber daya yang menimbulkan distribusi pendapatan timpang, penduduk miskin hanya memiliki sumber daya dalam jumlah yang terbatas dan kualitasnya rendah.

\section{Kesimpulan}

Adapun kesimpulan dari penelitian ini adalah:

Pertama, berdasarkan indikator Efektivitas. Peneliti menyimpulkan bahwa program Pelatihan menjahit oleh Dinas Tenaga Kerja dan Transmigrasi Kabupaten Serang dalam rangkaian Program P2WKSS belum optimal hasilnya. Hal ini dapat terlihat bahwa tidak ada kemajuan dari penerima program. Hal tersebut terjadi karena kurangnya motivasi guna meningkatkan kreativitas serta kurangnya menstimulus keinginan untuk meningkatkan taraf hidup masing-masing warga. Pada dasarnya, pelatihan yang diberikan merupakan langkah baik dalam mengubah suatu kondisi masyarat baik dari aspek ekonomi, sosial dan lain sebagainya. Akan tetapi jangka waktu bimbingan serta pelatihan yang diberi, tidaklah cukup untuk dapat memberikan 
konsistensi mereka dalam berkelanjutan. Adapun faktor lainnya, masayarakat tidak tidak terfasilitasi, baik dicarikan market, dan sasaran konsumen dan penyaluran tenaga kerja. Sehingga masyarakat kurang berkembang, dan tidak mampu mendirikan ekonomi kreatif yang mandiri. Akibat hal tersebut, berimbas kepada tujuan program P2WKSS belum tercapai.

Kedua, berdasarkan indikator Efisiensi. Peneliti menyimpulkan bahwa efesiensi usaha pelaksana program pelatihan menjahit Dinas Tenaga Kerja dan Transmigrasi Kabupaten Serang dalam pogram P2WKSS belum terlaksana dengan maksimal. Program pelatihan ini hanya berlangsug selama 25 hari. diketahui bahwa Dinas Tenaga Kerja dan Transmigrasi Kabupaten Serang hanya berfokus pada meningkatkan keterampilan penerima program. Hal ini berakibat pada kurangnya pemahaman penerima program terkait pentingnya dari adanya program.

Tidak dimanfaatkannya momentum pelatiahan ini secara baik, terkhusus pada aspek sosialisasi mengakibatkan kurangnya pemahaman masyrakat pada hal utama program, yaitu pengentasan kemiskinan. Padahal sosialisasi merupakan langkah pertama dalam pelaksanaan suatu program.

Dalam pelaksanaan Program P2WKSS di Desa Sangiang dan Bale Kencana, sosialiasi yang digunakan ialah dengan metode tidak langsung, metode ini mungkin efisien dalam segi waktu, akan tetapi kurang menjamin dari segi hasil karena masyarakat tidak mendapatkan informasi langsung dari sumbernya.

Ketiga, berdasarkan indikator Kecukupan. Peneliti menyimpulkan bahwa program ini sebenarnya sudah mencapai indikator ini dengan baik. Meninjau dari pencapaian sasaran tertentu dengan biaya tertentu. Dalam pencapaianya, diketahui bahwa pencapaian sasaran (3R), yaitu Rawan Ekonomi, Rawan Pendidikan dan Rawan Kesehatan, sudah dapat mecapai sasaran yang ditentukan. Jangkauan jumlah target sasaran program tidak mampu lebih dari $100 \mathrm{KK}$ pada tiap pelatihan yang ada. Hal ini berarti bahwa pencapaian sasaran dengan biaya tertentu, sudah dapat dikatakan sesuai dengan anggaran yang dimiliki. Jika kita melihat dari sudut pandang biaya.

Namun kemudian muncul permaslahan yaitu dalam lokasi program terdapat lebih dari $100 \mathrm{KK}$, sehingga memunculkan kecemburuan sosial di dalam masyarakat. Desa Sangiang Khususnya warga kampung pasir gadung terdapat $300 \mathrm{KK}$, dan $126 \mathrm{KK}$ di Desa Bale Kencana. Hal ini tentunya menjadi tantangan baik bagi pelaksana kegiatan, leading sector serta perangkat desa. Dimana tentunya merasa harus mampu memilah dan menentukan warga mana yang layak menerima program. Berkaitan dengan kecemburaan yang timbul pada lingkup masyarakat yang tidak bergabung menjadi penerima program pihak kelurahan hanya mampu memberi pengertian.

Pada pelatihan menjahit yang diberikan oleh Dinas Tenaga kerja dan Transmigarasi Kabupaten Serang, diketahui bahwa sasaran target terbesar ada pada tingkat pendidikan terendah yaitu SD, sekitar 50 persen.

Keempat, berdasarkan indikator Pemerataan. Pada pelaksanaan Program Pelatihan menjahit di Kecamatan Mancak, dapat disimpulakan bahwa pendistrubusiaan program pada penerima program telah mereta. Hal ini karena dalam 
tiap pelatihan, menjahit, para penerima program yang terdiri dari 20KK pertiap desa, mendapat materi pembelajaran yang sama. Pemerataan Bantuan yang didapat oleh warga penerima program dari Program P2WKSS ini sebenarnya sudah sesuai dengan aturan yang ditetapkan.

Kelima, berdasarkan indikator Responsivitas. Dari hasil penelitian dapat disimpulkan bahwa pelaksanaan program P2WKSS tersebut mendapatkan respon yang baik dari masyarakat, terutama masyarakat yang menjadi penerima program tersebut. Para penerima program mengungkapkan bahwa mereka senang dengan adanya pelatihan yang diberikan.

Keenam, berdasarkan indikator Ketepatan. Pada indikator ini, peneliti melihat bahwa program P2WKSS tersebut, sangatlah bermanfaat bagi mereka warga penerima program. Dimana mereka mampu memiliki keterampilan baru, dan bisa membuka usaha. Pelaksana kegiatan berharap bantuan yang diberikan dapat memberikan manfaat kepada masyarakat yaitu adanya peningkatan ekonomi, sehingga warga penerima program bisa membuka usaha, serta adanya perbaikan dari aspek kesehatan. Namun untuk pencapaian tujuan tersbut belum dapat tercapai.

\section{Referensi}

Agustino. Leo,(2016), Dasar-dasar Kebijakan Publik. Bandung: Cv Alfabeta

BPS Kabupaten Serang. 2017. Kecamatan Mancak dalam Angka 2017 https://serangkab.bps.go.id/publication/2017/09/27/c8c55bbdd699e7806f1cad c5/kecamatan-mancak-dalam-angka-2017.html

Bappeda. 2017. Jumlah Keluarga Menurut Kecamatan dan Status TKS https://bappeda.bantenprov.go.id/upload/DALAM\%20ANGKA\%20KAB-

KOTA/KAB\% 20SERANG/Kabupaten-Serang-Dalam-Angka-2017.pdf

BPS Provinsi Banten. 2017 Jumlah Penduduk Miskin di Provinsi Banten. https://banten.bps.go.id/publication/2017/08/11/5f4152f5abfb13c7f9f4de4e/provinsibanten-dalam-angka-2017.html

Eby F Ginting. (2017). Evaluasi Pelaksanaan Program Terpadu Peningkatan Peranan Wanita Menuju Keluarga Sehat dan Sejahtera (PT-P2WKSS) di Kelurahan Sempakata, Kecamatan Medan, Selayang Kota Medan. Retrieved from http:/ / repository.usu.ac.id/handle/123456789/65738

Febry Arif Fadilah. (2013). Analisis Pelaksanaan Kegiatan Peningkatan Peranan Wanita Menuju Keluarga Sehat Sejahtera (P2WKSS) di Desa Lipai Bulan Kecamatan Kerutuan Kabupaten Pelalawan Periodde 2013. Retrieved from https://jom.unri.ac.id/index.php/JOMFSIP/article/view/13809

Heskiela Adhi Wibowo.( 2017). Dampak Program P2wkss Terhadap Kesejahteraan Keluarga Miskin Di Kelurahan Keparakan, Kecamatan Mergangsan, Kota Yogyakarta. Retrieved from http:/ / onesearch.id/Record/IOS3794.slims-1868 
Hikmawan, M. D. (2017a). Pluralisme Demokrasi Politik di Indonesia. Journal of Governance, 2(2), 223-247. https:// doi.org/http:// dx.doi.org/10.31506/jog.v2i2.2678

Hikmawan, M. D. (2017b). Politik Perbedaan: Minnoritas dalam Implementasi Kebijakan. Journal of Indonesian Public Administration and Governance Studies (JIPAGS), 1(1), 88-98.

Hikmawan, M. D., \& Hidayat, R. (2016). Depoliticisation of Public Issue : Low Degree of Government' S Democratic Legitimacy. Journal of Governance, 1(1), 23-37.

https://doi.org/http://dx.doi.org/10.31506/jog.v1i1.1311

Nugroho. Riant, (2008). Kebijakan Publik, Formulasi, Implementasi dan Evaluasi. Jakarta: PT. Elex Media Komputindo

Peraturan Menteri Dalam Negeri Nomor 26 Tahun 2009 Tentang Pedoman Pelaksanaan Peningkatan Peranan Wanita Menuju Keluarga Sehat Dan Sejahtera di Daerah

Sugiyono. (2010). Metode Penelitian Pendidikan Pedekatan Kuantitatif, Kualitatif dan R\&D. Bandung: Alfabeta 